\title{
Reform and Practice of the Teaching and Assessment Methods for the Metal Cutting Machine Tool Design Course Based on Project Teaching Method
}

\author{
Jianjun Yang ${ }^{a}$, Changhe $\mathrm{Li}^{\mathrm{b}}$, Hong Zhan ${ }^{\mathrm{c}}$ and Zilong Peng ${ }^{\mathrm{d}}$ \\ School of Mechanical Engineering, Qingdao University of Technology, Qingdao 266520, China \\ ajjjdem@163.com, bsy_lichanghe@163.com, 'chhde@163.com, 'pzImail@163.com
}

Keywords: The metal cutting machine tool design course; teaching reform; project teaching method; $\mathrm{CDIO}$; diversified assessment method; ability training.

\begin{abstract}
Assessment is the basic way to evaluate and improve the teaching. The traditional assessment method usually is single classroom examination, and is not conducive to the improvement of students' comprehensive quality. In order to realize the cultivation of various abilities of students, we have reformed the teaching and assessment methods of the metal cutting machine design course. The project teaching model of the course is constructed based on CDIO teaching idea, and the content of the project is to implement the virtual simulation design of machine tool transmission system. The project, experiment, attendance, classroom comprehensive performance, small test, homework are all included in the course evaluation index system. Practice shows that the teaching reform effect is obvious, and the students' active learning and ability training are achieved.
\end{abstract}

\section{Introduction}

The core mission of institution of higher education is to cultivate talents, teaching work is the central work of the school, teaching quality is the lifeline of institution of higher education. Scientific and reasonable assessment methods have a great effect on teaching, which is beneficial to the improvement of the teaching quality [1]. Assessment should be the basic way to evaluate and improve the teaching, so that the teaching is conducive to the cultivation of innovative talents. Assessment should be an important means to guide students to take the initiative and creative learning. Assessment should be an important link to test and improve students' creative thinking and ability.

The present examination systems affect the importance attached to the professional courses. On the one hand, in the postgraduate entrance examination, the public basic courses are the main courses. On the other hand, the examination forms of the current professional courses are mainly based on the content of the textbook, the students have formed the habit of reviewing their lessons within a short time, and it is easy for students to ignore the study of professional courses.

Most of the traditional assessment methods are a single classroom examination, it is limited to the examination of understanding and mastering of classroom knowledge, not conducive to the improvement of students' comprehensive quality, unable to develop students' self-learning ability, practical ability, innovative ability, and critical spirit, questioning consciousness [2], but these abilities and consciousnesses for the students are more important and should be placed in a prominent position.

At present, the reforms of the assessment method are more and more attention to the process of learning, course assessment method using a number of process assessment combined with final examination. For example, attendance, homework, small papers, etc [3, 4]. CDIO engineering education model is the latest achievement of international engineering education reform in recent years [5]. CDIO education model not only pay attention to the teaching and learning of abstract theoretical knowledge, and emphasizes the importance of doing in the teaching process, it can enhance the students practical ability and to cultivate the students' innovation consciousness, project design capacity and team work spirit. The curriculum knowledge structure can be organically linked to the whole process of study and practice [6]. 
The metal cutting machine tool design course is a course that is closely combined with practice. The theoretical knowledge of the course has certain difficulty, and learning initiative of students is not high, so the rate of failure is higher for many years, the failure rate is usually around $30 \%$. Therefore, it is imperative to carry out course reform.

The education idea of CDIO being used for reference, process assessment is emphasized, the teaching and assessment methods of the metal cutting machine tool design course are constructed, in which the ability training as the goal, the project driven as the basis.

\section{Project Teaching Method Based on CDIO}

Drawing on the idea and model of CDIO engineering education, taking the ability of the students as the guide, the project teaching model of the course of metal cutting machine tool design is constructed, in that the student as the main body, the course project as the basis, the organic integration of theory and practice, and knowledge, ability, quality in one.

The course teaching mode based on project driven can realize two processes at the same time. One is the learning process of knowledge, it emphasis on the whole process of establishment, master and comprehensive application of the knowledge. Two is the training process of the ability, the learning ability, engineering practice ability, teamwork, communication and expression ability, innovation ability, social ability and so on as the core of the ability training.

The knowledge learning and ability training is an organic whole, the traditional teaching mode can't realize the organic combination of the two.

Through the implementation of the project, the organic integration of the theoretical system, experimental and practical teaching is realized, and the two processes of knowledge learning and ability training are realized simultaneously, the principle as shown in Fig.1.

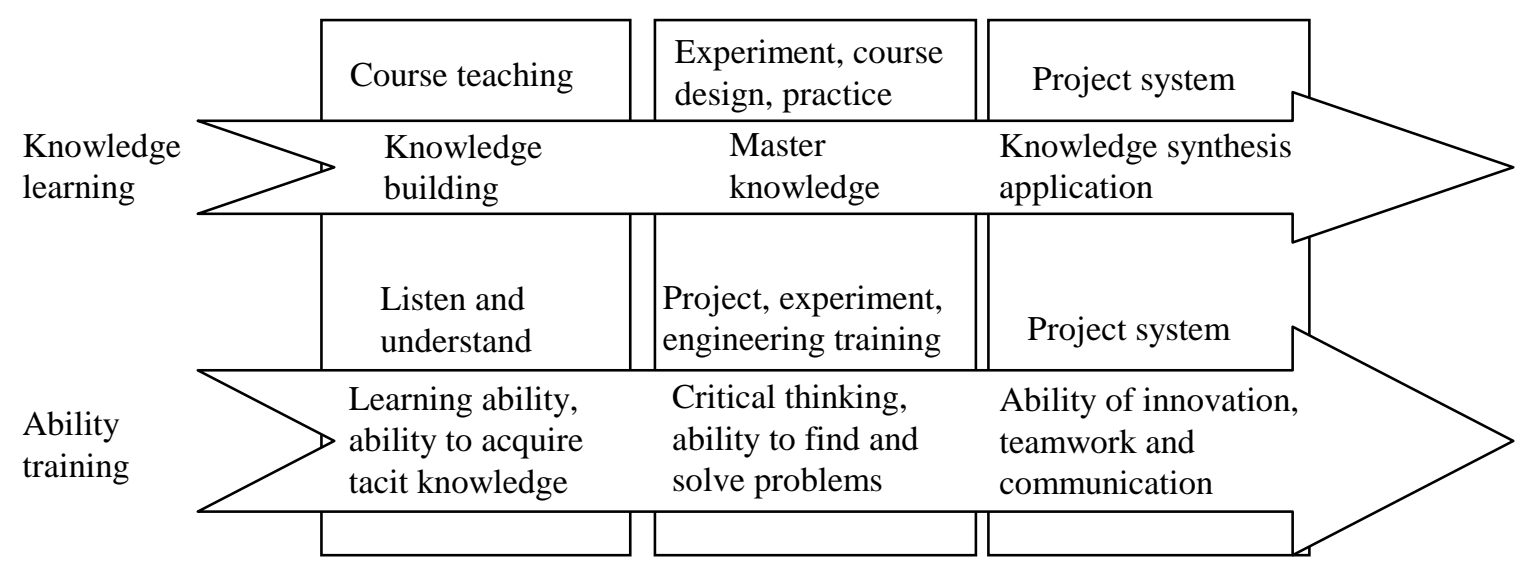

Fig. 1 Knowledge learning and ability training based on project driven

According to the teaching content of the course of metal cutting machine tool design, the design of the transmission system of the machine tool is the main line of the teaching material, so it is determined that the content of the projects are to design the main drive system and the feed drive system of the machine tool. In view of the complexity of the system structure and high processing precision, production is not realistic, but it is feasible to combine the computer aided design to realize the three dimensional virtual simulation. In the process of three dimensional virtual simulation, the course contents of mechanical principle, mechanical design, mechanical manufacturing basis, mechanical manufacturing technology and other courses will be related to, so that students can get a comprehensive training.

The specific implementation steps of the project teaching method are as follows:

(1) The establishment of the project team. Members of the group composed of about five students, and one group leader is selected by the students and is responsible for the work of the project.

(2) Project preparation. According to the teaching objectives of the course, the main drive system or the feed drive system of one kind of machine tool is selected, and is given to each group at the 
beginning of the course. In the course of the whole teaching process, the students analyze the transmission system and put forward problems.

(3) Project implementation. Students according to the specific tasks of the project to implement the project content, the project is broken down into a number of small tasks and completed by each member of the group. In the course of project implementation, teachers should solve the problems in the implementation of the project, do a good job of assistant and supervision, and ensure the smooth implementation of the project.

(4) Analysis and discussion. In order to achieve the expected goal of the project, the teams regularly analyze and discuss the project implementation results, reach a consensus, and assign the next step of the project plan.

(5) Assessment. After the completion of the project, each project team to report, teachers evaluate the project completion and the quality, at the same time, the assessment results should also include the self rating scores of the project team members.

\section{Diversified Assessment Method Design}

The assessment of students' design ability, practical ability and innovative ability can be carried out in the following links: project teaching, experiment, classroom questioning, discussion, etc.

In order to pay attention to the process of learning, the project, experiment, attendance, classroom comprehensive performance, small test, homework and other aspects are included in the course evaluation index system. At the same time, the cultivation of students' moral character is emphasized. In each assessment, learning attitude, ideology and morality, integrity awareness, team spirit and many other aspects are considered simultaneously. The method can enable students to actively participate in teaching activities, can comprehensively assess the students' knowledge, ability and quality, and implement the whole process management of the students' course study. The style of study and examination are promoted ultimately.

Before reform, the final results of the course was composed of the following parts, final examination results was $80 \%$, attendance was $10 \%$, and the experiment was $10 \%$.

After the reform, the final results of the course is composed of the following parts, final examination results is $52.5 \%$, classroom comprehensive performance and small test is $10.5 \%$, attendance is $7 \%$, experiment is $10 \%$, homework is $6 \%$, and project is $14 \%$. As shown in Fig. 2 . The full mark of each part is 100 points. The initial attendance score is 100 points, a certain score is reduced when absent, and absenteeism and leave are treated differently. The initial score of classroom comprehensive performance is 60 points, in order to encourage participation in the discussion, answer questions, and serious listening, etc.

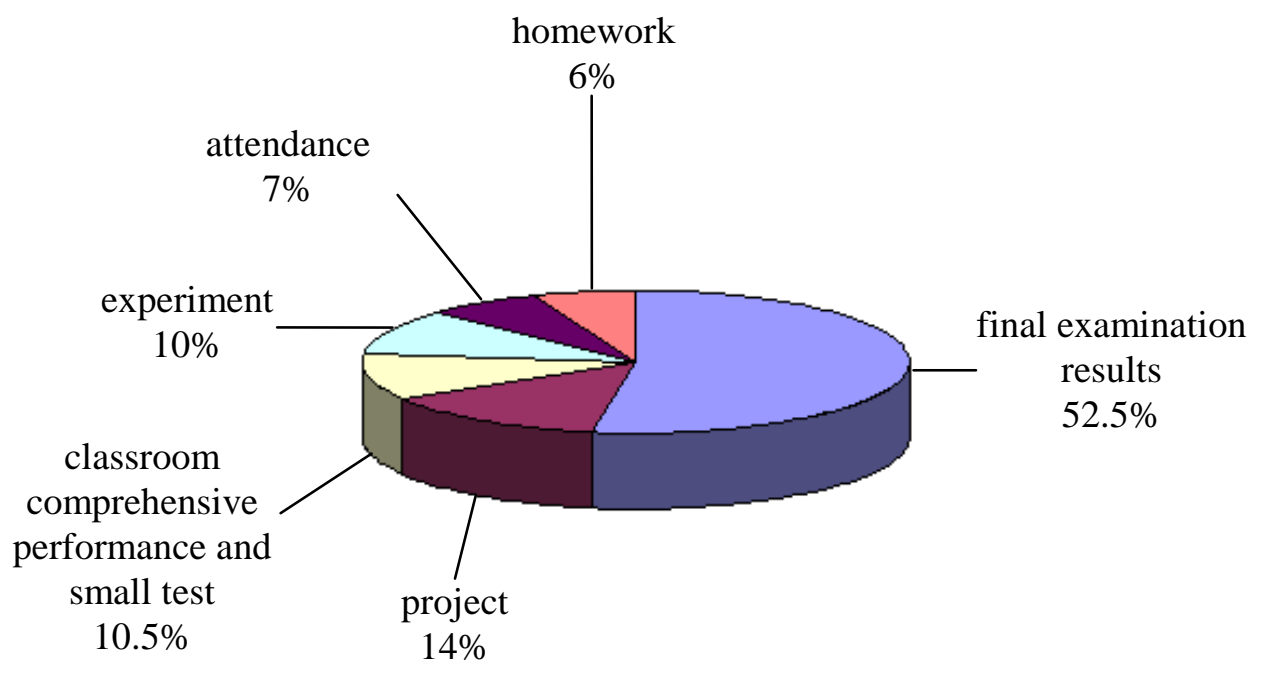

Fig. 2 The composition diagram of final results 


\section{Implementation Effect}

After the reform, the students' learning initiative and the learning effect have been improved significantly. The data comparison of results before and after reform is shown in Table 1, the histograms of final examination results distribution before and after reform are shown in Fig.3, Fig.4 respectively. The number of students attending class is 88 in the last academic year, the number experimental classes is 28 in this academic year.

Table 1 Comparison of results before and after the reform

\begin{tabular}{|c|c|c|c|c|}
\hline \multirow[b]{2}{*}{$\begin{array}{l}\text { The interval } \\
\text { of results }\end{array}$} & \multicolumn{2}{|c|}{$\begin{array}{l}\text { The number and proportion in } \\
\text { the interval before reform }\end{array}$} & \multicolumn{2}{|c|}{$\begin{array}{l}\text { The number and proportion in } \\
\text { the interval after reform }\end{array}$} \\
\hline & $\begin{array}{l}\text { The final } \\
\text { examination } \\
\text { results }\end{array}$ & $\begin{array}{l}\text { The final } \\
\text { results of the } \\
\text { course }\end{array}$ & $\begin{array}{l}\text { The final } \\
\text { examination } \\
\text { results }\end{array}$ & $\begin{array}{l}\text { The final } \\
\text { results of the } \\
\text { course }\end{array}$ \\
\hline $0 \sim 59.9$ & 46 (52.27\%) & 15 (17.05\%) & $1(3.57 \%)$ & $0(0 \%)$ \\
\hline $60 \sim 69.9$ & 19 (21.59) & 31 (35.23\%) & $1(3.57 \%)$ & $0(0 \%)$ \\
\hline 70 79.9 & 15 (17.05\%) & 26 (29.55\%) & 10 (35.71\%) & $1(3.57 \%)$ \\
\hline 80 89.9 & 8 (9.09\%) & 16 (18.18\%) & $12(42.86 \%)$ & 20 (71.43\%) \\
\hline $90 \sim 100$ & $0(0 \%)$ & $0(0 \%)$ & 4 (14.29\%) & 7 (25.00\%) \\
\hline
\end{tabular}

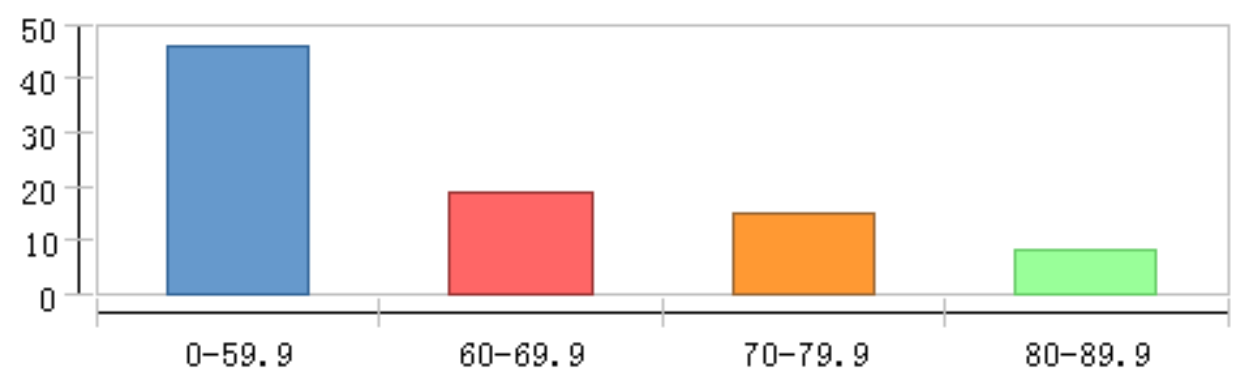

Fig. 3 The histogram of final examination results distribution before reform

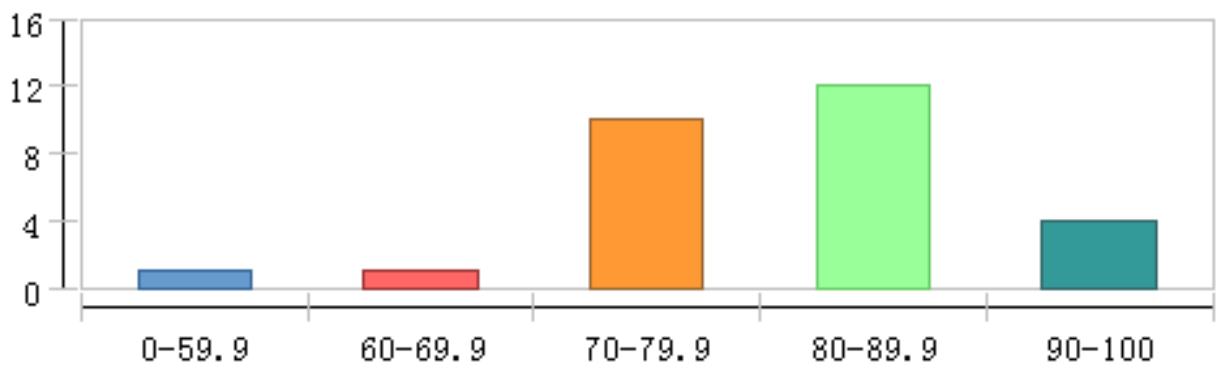

Fig. 4 The histogram of final examination results distribution after reform

Through the reform, not only the students' academic record has been improved, but also the students' comprehensive ability has been exercised. At the end of term, students give a high evaluation for the course reform.

\section{Conclusion}

In order to realize the training of practical ability, innovative ability, learning ability, team spirit and other aspects, and the comprehensive evaluation of students, we have carried out the reforms of the teaching and assessment methods for the course of metal cutting machine tool design. Drawing on the idea of CDIO, the project teaching model is constructed, and the diversified assessment method of the whole process is designed. The effectiveness of the method is illustrated by the comparison of results and student feedback. 


\section{Acknowledgment}

In this paper, the research was sponsored by the research project of teaching reform in undergraduate colleges in Shandong Province (Project No. 2015M087).

\section{References}

[1]. J.Y. Zhang, J.B. Xu, and J. Feng, "the reform of examination methods and methods,” Modern Property, vol. 12, No. 2, pp. 52-53, February 2013. (In Chinese)

[2]. C.H. Li, Y.L. Hou, and G. Y. Liu, "Expanding of college students' scientific quality and innovation with the carrier of research program”, Advanced Materials Research, Vols. 171-172, pp. 90-93, January 2011.

[3]. E.H. Zhang, "An analysis of the teaching strategies of mechanical specialty course," Heilongjiang Researches on Higher Education, vol. 31, No. 7, pp. 169-171, July 2012. (In Chinese)

[4]. C.H. Xu, "Experimental study on the reform of examination mode and method of electronic commerce course,” China Management Informationization, vol. 13, No. 15, pp. 114-116, August 2010. (In Chinese)

[5]. W.Y. Chen, "The research of the teaching mode based on the concept of CDIO architectural design,” Applied Mechanics \& Materials, vol. 584-586, pp. 2753-2756, July 2014.

[6]. J.Y. Wang, X.C. Nie, and X.D. Zhang, "Study and practise of talent training mode of mechanical speciality based on CDIO project education idea,” Equipment Manufacturing Technology, vol. 40, No. 10, pp. 218-221, October 2012. (In Chinese) 